Marek Cetwiński

Akademia im. Jana Długosza w Częstochowie

\title{
CO DAJE LEPSZE KORZYŚCI - „STAN BADAŃ” CZY „HISTORIA PROBLEMU”?
}

What brings more Benefits - "State of Research" or "History of a Problem"?

Scientific work - according to definition of S. Kościałkowski - is only a work that discusses new issue or presents new arguments for a thesis being subject to scientific discussion. The requirement of newness entails the requirement of erudition - in the choice of research topic and proposed solution of a problem - knowledge of the problem's history. Simply - knowledge in the history of historiography, perceiving historiography as testimony to the time when it was created, analysis of cultural, ideological and political factors, which were decisive in acceptance or rejection of theses propagated in science. For this reason "history of a problem" is always an inherent part of its solution.

Keywords: definition of scientific work, factors shaping historiography, history of historiography

Słowa kluczowe: definicja pracy naukowej, czynniki kształtujące historiografię, historia historiografii.

„W jaki sposób i na podstawie, jakich przesłanek wyboru tematu dokonywać mamy?"- Pytał Stanisław Kościałkowski w podręczniku dla początkujących historyków ${ }^{1}$. Natychmiast też odpowiadał:

Za temat pracy badawczej obrać należy sprawę ważną (albo przynajmniej wygląda-

jącą na taką), która podlega dyskusji naukowej i nie jest dotąd rozstrzygnięta, albo

zgoła dotychczas badana nie była jeszcze ${ }^{2}$.

Inaczej rzecz nieco ujmując - pisać należy tylko wówczas, kiedy mamy cokolwiek nowego do powiedzenia.

1 S. Kościałkowski: Historyka. Wstęp do studiów historycznych, Londyn 1954, s. 151.

${ }^{2}$ Tamże, s. 151. 
Wybór tematu badawczego wymaga, więc erudycji. Znajomości historii historiografii po prostu. Choćby po to tylko, aby zyskać pewność, iż wybrany temat rzeczywiści jest ważny, nowy lub przynajmniej dotąd nierozstrzygnięty.

Gdy przystępujemy - ciągnie Kościałkowski - do naukowego opracowania jakiegokolwiek zagadnienia powinniśmy zebrać i poznać wszystko, cokolwiek o tym zagadnieniu pisano: w jakimkolwiek języku, gdziekolwiek i kiedykolwiek. Niczego, absolutnie niczego nie wolno nam przeoczyć, pozostawić bez uwzględnienia. Jeżeli gdybyśmy cokolwiek pominęli - przestrzega cytowany autor - do czegoś nie zajrzeli, czegoś nie poznali: narazilibyśmy się na słuszny zarzut, że jesteśmy dyletantami, że praca nasza jest dyletancka, nie sumienna, na której polegać nie można³

Uwagi Kościałkowskiego brzmią dziś równie staroświecko jak jego składnia. Nieporównanie mniejsza była przecież w jego czasach literatura historyczna. Przeglądając bibliografie dawnych koryfeuszy polskiej mediewistyki uderza skromna w porównaniu z obecnymi lista publikowanych prac. Przykładem służy choćby twórczość Tadeusza Manteuffla, który przez 38 lat opublikował - wliczając w to recenzje, sprawozdania i wspomnienia - 121 tekstów ${ }^{4}$. Stefan Czarnowski w ciągu 33 lat opublikował nieco ponad sto, przeważnie zwięzłych, kilkustronicowych utworów. Nie stronił też od publikowania w tygodnikach, czyli w periodykach dziś „niepunktowanych”. . Nikt z dawnych naszych historyków nie był poddany presji zdobywania punktów. Nie był też rozliczany przez biurokratów z ilości publikacji, lecz przez naukowe środowisko z ich, jakości. Brak pośpiechu i narzuconej przez biurokrację atmosfery swoistego „wyścigu pracy” korzystnie odbiegały od warunków, w jakich dziś znajdują się humaniści. Pisano kiedyś mniej, ale staranniej i to już powinno skłaniać do uważniejszej lektury prac naszych poprzedników w rzemiośle. Tym bardziej, że celem tych prac - przynajmniej większości z nich - było rozwiązanie naukowego problemu a nie zdobycie kolejnego stopnia lub tytułu naukowego.

Precyzyjne określenie warunków, w jakich powstawała taka lub inna praca powinno być, przeto punktem wyjścia do dalszych refleksji nad jej znaczeniem i miejscem w całości historiograficznego dorobku. Po prostu, jak ujął to Jan Adamus, należy „patrzeć na naukę historyczną, jako na wyraz czasu, w którym powstawała”. „Takie historyczne podejście do historiografii - kontynuuje swój wywód ten wybitny historyk prawa - pomaga nam wyzwolić się z rozmaitych dogmatów,

\footnotetext{
${ }^{3}$ Tamże, s. 8.

${ }^{4}$ E. Wi d e rs zal owa: Bibliografia prac profesora dra Tadeusza Manteuffla za lata 19241961, w: Wieki średnie. Medium aevum. Prace ofiarowane Tadeuszowi Manteufflowi w 60 rocznice urodzin, Warszawa 1962, s. 7-19.

${ }^{5}$ Bibliografia prac Stefana Czarnowskiego, w: S. Czarnowski: Dzieła, t. V. Publicystyka, posłowie, wspomnienia, oprac. N. Assorodobraj, S. Ossowski, Warszawa 1956, s. 187-192.

${ }^{6} \mathrm{~J}$. A d a mu s : Ideologia feudalna w Polsce wieku X-XII, „Studia Wczesnośredniowieczne”, t. IV, 1958, s. 109.
} 
które nie były niczym innym, jak ideologią pewnych historyków"7. Kryje się za tymi słowami postulat poznania poglądów stojącego za tekstem jego autora. Jego przekonań teoretycznych, ideologicznych a nawet politycznych. Wreszcie też wpływu, jaki wywierał na środowisko. Nie należy, bowiem do rzadkości, że wysoce wątpliwa hipoteza zgłoszona przez naukowy autorytet zyskuje powszechną aprobatę tylko, dlatego właśnie, iż jej autor cieszy się powszechnym uznaniem. Przykładem służy wprowadzenie przez Gerarda Labudę do naukowego obiegu zaginionego rzekomo


tuszewskiego wykazującego całkowitą bezpodstawność konstrukcji Labudy nadal wielu historyków wykorzystuje pomysł o istnieniu tego domniemanego źródła do snucia dalszych domysłów ${ }^{9}$.

Nie tylko wybitne jednostki narzucają historiografii swoisty gorset pojęciowy krępujący zwłaszcza początkujących badaczy. Podobne skutki wywołuje „plebiscytowa teoria prawdy" - uznanie za trafne tego, co za takie uważa większość badaczy. W tym przypadku należy ustalić przyczyny odrzucenia lub przemilczenia poglądów sformułowanych w zgodzie z surowymi wymaganiami warsztatowej poprawności. W cytowanym wyżej sporze o tzw. RKD to puryzm metodologiczny Józefa Matuszewskiego a nie poza źródłową koncepcję Gerarda Labudy uznał Władysław Sobociński za „beletrystykę wysokiej klasy”, której istotę stanowi „zawzięta nieufność” do przekazu Długosza $^{10}$. To klasyczne odwrócenie pojęć wzmocniło żywotną już wcześniej skłonność do zastąpienia dążenia do ustalenia tego, co pewne w historii tym, co tylko prawdopodobne, choćby w niewielkim stopniu. W tle tego sporu widnieje też obawa, że rygorystyczne przestrzeganie zasad krytyki głoszącej konieczność potwierdzenia faktu drugim niezależnym źródłem doprowadzi do rezygnacji z wielu uznawanych w literaturze wydarzeń z dziejów Polski średniowiecznej. Żąda się, więc aby „nie dyskwalifikować pochopnie prawdziwości przekazów"11. Wymóg znalezienia drugiego niezależnego źródła to nawet, głosi się, krytyka „nihilistyczna”"12. Nie dziwi wobec tego, że

\footnotetext{
7 Tamże.

${ }^{8}$ G. L a bu d a : Zaginiona kronika w Rocznikach Jana Długosza. Próba rekonstrukcji, Poznań 1983.

${ }^{9}$ J. Matus zew ski: Relacja Długosza o najeździe tatarskim w 1241 roku. Polskie zdania legnickie, Łódź 1980; te n ż e, Spór o zaginionq kronikę, w: te n ż e: Pisma wybrane, t. IV, Łódź 2001, s. 205-227. Całość sporu omawiam: M. Cetwińs ki : Spór o istotę historii. Dyskusja wokół bitwy legnickiej w najnowszej historiografii, w: t e n ż e : Metamorfozy śląskie. Studia źródłoznawcze i historiograficzne, Częstochowa 2002, s. 171-184.

${ }^{10}$ W. S o b o c iń s ki : Roczniki czyli kroniki Długosza jako źródło do dziejów Polski w pierwszej połowie XIII wieku (Uwagi w zwiq̨zku z praca Gerarda Labudy „Zaginiona kronika z pierwszej połowy XIII w.”), „Czasopismo Prawno-Historyczne”, t. 36: 1984, s. 215, 218. Por. J. M a t us z e w s ki : Zaginiona kronika (RKD) Gerarda Labudy w oczach W. Sobocińskiego, w: te nż e : Pisma wybrane, t. IV, Łódź 2001, s. 275-290.

${ }^{11}$ W. Sobociński: s. 218.

12 Tamże, s. 215 przyp. 22. Natomiast S. Ko ściałkow s ki : s. 110:
} 
pochodzącą z początku XVI wieku „Kronikę Piotra komesa” uznano za wierny przekaz treści rzekomo XII-wiecznego poematu „Carmen Mauri”13. Względne ubóstwo źródeł do polskiego średniowiecza i wywołany tym lęk przed domniemaną faktograficzną pustką prowadzi, jak świadczy wspomniany przypadek, do popularności metody antykwarycznej. Zapomina się, bowiem o zjawisku amplifikacji, tj. rozwijania wcześniejszych przekazów o nowe wątki ${ }^{14}$. Natomiast ułożenie źródeł oraz literatury przedmiotu według chronologii ich powstawania pozwala poznać rozwój konkretnej opowieści . Wyraźniej widać wówczas jak pierwotna, często lakoniczna wzmianka obrasta nowymi szczegółami pod piórem kolejnych autorów. Łatwiej też wówczas stwierdzić jak sformułowana kiedyś hipoteza, lub zwykły domysł przemienia się w rozprawach kolejnych badaczy w pewnik, na którym buduje się kolejne, równie chybotliwe, domysły.

Na historyka podejmującego pracę czyha, zatem niejedna pułapka. Wielu ukrytych założeń w wykorzystywanej literaturze może zwyczajnie nie dostrzec. Tym bardziej, że istniejący system wymusza na nim pośpiech i zwyczajnie brak mu czasu na wnikliwą analizę historiograficzną ${ }^{15}$. W przypadku prac awansowych należy też liczyć się z reakcją

Jeżeli fakt jakiś podany i stwierdzony został tylko przez jedno znane nam źródło, to z reguły nie uważamy go jeszcze za bezwzględnie ustalony i nie ulegający wątpliwości. Nie wchodzi on jeszcze do poznania naszego, jako fakt całkowicie pewny". Tamże s. 111: „za pewny i stwierdzony istotnie uznajemy fakt, który stwierdzają przynajmniej dwa autentyczne i wiarygodne źródła, przy tym podkreślmy to raz jeszcze: przynajmniej dwa źródła, całkowicie od siebie niezależne. Tylko fakty w ten sposób (tj. najmniej przez dwa źródła niezależne) stwierdzone uchodzić mogą za ustalone i pewne". Wyjaśnia też natychmiast: „Za źródła niezależne będziemy tu uważali takie źródła, które nie tylko są oparte na dwu lub kilku niezależnych od siebie obserwacjach, ale nie mają też wspólnego, identycznego podłoża ideowego i psychicznego.

${ }^{13}$ Szerzej zob. M. C etwiń s ki : Historia i polityka. Teoria i praktyka mediewistyki na przykładzie badań dziejów Śląska, Kraków 2008, s. 173-188.

${ }^{14} \mathrm{Na}$ mechanizm amplifikacji zwracali uwagę L. Schulte: Ist die Namensform Mieczko berechtigt? Eine quellenmäßige Untersuchung, „Zeitschrift des Vereins für Geschichte und Alterthum Schlesiens", t. 50: 1916, s. 68-129; t e n ż e: Die älteste polnische Nationalsage, tamże, t. 49: 1915, s. 100; J. Kl a p p e r : Die Tatarensage der Schlesier, „Mitteilungen der schlesischen Gesellschaft für Volkskunde", Bd. 31/ 32: 1931, s. 160-196.

${ }^{15}$ Znajomość historii historiografii nie jest najmocniejszą stroną polskich historyków. I tak W. Wr z o s e k: Historia, kultura, metafora. Powstanie nieklasycznej historiografii, Wrocław 1995, s. 62 uważa, że „nowa historia cen powstała w latach 1929-1933” we Francji jako skutek Wielkiego Kryzysu. W rzeczywistości już w 1906 r. Franciszek Bujak uznał badanie cen za najważniejsze zadanie historii gospodarczej. Zob. też: S. H o s z o w s ki: Historyczne badanie cen, „Roczniki Dziejów Społecznych i Gospodarczych”, R.1: 1931, s. 53-77. D. Skota rczyk: Wprowadzenie od redaktora naukowego, w: P. Burke: Historia kulturowa. Wprowadzenie, tłum. J. Hunia, Kraków 2012, s. 7 pisze: „W naszym kraju o historii kulturowej raczej się nie słyszało, a w każdym razie nie słyszało do niedawna”. W ten sposób pominęła dorobek A. Brücknera, K. Chłędowskiego, W. Łozińskiego, B. Baranowskiego, K. Opałka i wielu innych. Fascynacja francuską szkołą „Annales” nie pozwala też dostrzec, że K. P o tkań s ki : O pochodzeniu wsi polskiej, w: tenże: Pisma pośmiertne. W opracowaniu i ze wstępem Franciszka Bujaka, posłowiem opatrzył Jan M. Piskorski, Poznań 2004, s. 541 na długo przed Fernandem Braudelem sformułował teorię „długiego trwania”. 
recenzentów nieraz nadmiernie przywiązanych do własnych hipotez. A to często skutkuje konformizmem. Przykładem służy choćby taka uwaga autorki pewnej monografii genealogicznej: „Przeglądu wcześniejszej literatury teoretycznej dokonał J. Adamus (Polska teoria rodowa, Łódź 1959) wysuwając jednak wiele kontrowersyjnych wniosków, obecnie powszechnie już kwestionowanych"16. Zwięzłe to skwitowanie obszernej, liczącej 348 stron erudycyjnej rozprawy jednego z najwybitniejszych polskich mediewistów połowy $\mathrm{XX}$ wieku ${ }^{17}$. Adamus udowadnia w jednym z rozdziałów pozaźródłowe pochodzenie polskiej teorii heraldyczno-genealogicznej ${ }^{18}$. Adamus wykazał, że wszelkie przyjmowane przez polskich heraldyków i genealogów tzw. kryteria należy odrzucić, jako niczym nieuzasadnione domysły. Wśród nich przede wszystkim przekonanie o istnieniu imion stanowiących jakby znak rozpoznawczy „rodu” oraz dogmat głoszący, iż zgodność herbu oznacza koniecznie pokrewieństwo ludzi pieczętujących się nimi. Kryteria te - i kilka innych równie wątpliwych - stały się podstawowymi narzędziami tzw. toruńskiej szkoły genealogicznej. Nic, więc dziwnego, że cytowane przez autorkę monografii „rodu” Wierzbnów opracowania traktujące o „szerokiej i nowoczesnej podstawie teoretycznej" stworzonej przez toruńskich genealogów o monografii Adamusa milczą ${ }^{19}$. Dodajmy, że recenzentami wydawniczymi monografii rodu Wierzbnów byli prominentni przedstawiciele szkoły toruńskiej. Ponadto odrzucenie krytycznych uwag Adamusa ma jedną niezaprzeczalną zaletę - rozprawy genealogiczne pisze się łatwo. I tak też można przecież pomnażać „dorobek” historiografii. Gmatwając przy okazji wykład historii przez utożsamienie owych „rodów” z partiami politycznymi aktywnymi już rzekomo w czasach pierwszych Piastów ${ }^{20}$.

Nieobecność myśli Jana Adamusa w rozprawach poświęconych genealogii potwierdza zarazem obserwację tego uczonego o istnieniu „sił zainteresowanych w petryfikacji dawnych podejść do problemu”, które skłonne są uczynić „wszystko, aby faktów i samego problemu nie dostrzec"21. Innym przykładem działania wspomnianych sił jest nieobecność w rozprawach poświęconych dyplomatyce jakiejkolwiek polemiki z tezami Stanisława Kurasia ${ }^{22}$. Kuraś odegrał, bowiem w dyplomatyce rolę

${ }^{16}$ A. Tarnas -To m c zyk: Ród Wierzbnów do końca XIV wieku. Genealogia i rozsiedlenie, Wrocław 1993, s. 7 przyp. 1.

${ }^{17}$ J. Ad a m u s: Polska teoria rodowa, Łódź 1958. Myli się więc A. Tar n as -To m c zyk: s. 7, datując wydanie na $1959 \mathrm{r}$.

${ }^{18}$ Tamże, s. 147-178 (rozdział zatytułowany - „Teoria heraldyczno-genealogiczna”).

${ }^{19}$ Obecna sytuacja w polskich badaniach genealogicznych zob. M. Cetwiński: Jak pisać rozprawy genealogiczne?, w: Rody na Śląsku, Rusi Czerwonej i w Małopolsce: średniowiecze i czasy nowożytne. Stan badań, metodologia, nowe ustalenia, red. W. Za wi t ko ws ka, A. Po bó g - L e n a r to wi c z, Rzeszów 2010, s. 9-19.

${ }^{20}$ Np. M. Plezi a : Wstęp, w: Anonim tzw. Gall, Kronika polska, Wrocław-Warszawa-Kraków 1965, s. XXIV-XXXI.

${ }^{21}$ J. A d a mu s: Monarchizm i republikanizm w syntezie dziejów Polski, Łódź 1964, s. 177.

${ }^{22}$ S. Kuraś: Przywileje prawa niemieckiego miast i wsi małopolskich XIV-XV wieku, Wrocław-Warszawa-Kraków 1971. 
podobną tej jak Adamus w genealogii - zakwestionował większość metod stosowanych przez dyplomatyków. Zanim, więc uznamy, iż jakiś pogląd został odrzucony przez „większość świata nauki” to zastanówmy się czy owa „większość” nie reprezentuje przypadkiem owych „sił skłonnych do petryfikacji”.

„Stan badań” zwykle ogranicza się do wyliczenia dotychczasowej literatury przedmiotu, często z pominięciem prac starszych lub zwyczajnie niewygodnych. Praktyka taka prowadzi zazwyczaj do „grzechu konfirmacji”, czyli wyszukiwania wyłącznie takich źródeł i autorów, którzy potwierdzają nasze poglądy. Zwłaszcza, kiedy są to poglądy uznane przez tych, których uważamy, słusznie lub nie, za autorytety. Referowanie stanu badań łączy się zwykle z ocenianiem, rzadziej natomiast ze zrozumieniem powodów skłaniających historyków do sformułowania konkretnych tez. Tymczasem lepiej jest, jak głosił Jan Adamus, badać nie tylko „stan sprawy”, ale też jej „rozwój”23. Odpowiedzieć na pytania, kto, kiedy i dlaczego pierwszy postawił dany problem. Kto i dlaczego zanegował ustalenia poprzedników? Musimy ustalić, do jakich kierunków naukowych lub filozoficznych dany historyk czuł sympatię, lub przeciwnie - niechęć. Słowem przekonać się „czy i jakie uwarunkowanie społeczno-polityczne zachodziło, co do rozmaitych teorii naukowych"24. Historyk świadomie, lub nie, wspiera lub neguje, w mniejszym lub większym stopniu, aktualną w jego czasach „politykę historyczną”, co nie pozostaje bez wpływu na formułowane przez niego ujęcie problemu ${ }^{25}$. Historia problemu jest więc w istocie częścią jego rozwiązania. Wprawdzie okazać się może, że całe to żmudne dochodzenie nie wniesie niczego istotnego dla osiągnięcia zamierzonego pierwotnie celu, to jednak pozwoli poznać jakiś fragment przeszłości naszej dyscypliny. Stanie się tym samym przyczynkiem do historii historiografii i nasz trud nie pójdzie na marne. A bez znajomości meandrów historii historiografii ocena „stanu badań", nawet dla przyczynkarskich zdawałoby się zagadnień, bywa wątpliwa ${ }^{26}$.

Tylko znajomość dorobku poprzedników oraz ścisłe przestrzeganie reguł warsztatu historycznego uchroni nas od pełnych domysłów publikacji o wątpliwej wartości naukowej. Takich o jakich pisał Janusz Bieniak:

Może i nie jest wykluczone, ale na pewno nic tu nie jest pozytywnie dowiedzione; na rzeczach <<niewykluczonych>> nie można budować żadnego dopuszczalnego wnioskowania. Tymczasem na tak grząskim (właściwie zerowym) fundamencie badacz ów tworzy wielopiętrową hipotezę ${ }^{27}$.

${ }^{23}$ J. Ad a mu s: Polska teoria..., s. 12.

${ }^{24}$ Tamże, s. 12.

${ }^{25}$ Szeroko zob. M. C e tw i ń s ki : Historia i polityka..., passim.

26 Znakomite wprowadzenie do dziejów współczesnej mediewistyki polskiej zob.: S. Kwiatkowski: Polska mediewistyka historyczna w czasach maszynopisu. O wymuszonej modernizacji i okolicznościach jej przemijania (wybrane zagadnienia), Poznań 2010.

${ }^{27} \mathrm{~J}$. B i e n i a k: Średniowieczne polskie rody rycerskie. Stan badań, problemy sporne, możliwości badawcze, w: Genealogia - stan i perspektywy badań nad społeczeństwem Polski średniowiecznej na tle porównawczym, red. J. Pa ku l s ki, J. Wr o n is s e w s ki , Toruń 2003, s. 69. 
A przecież celem badań historycznych zdefiniowanych już przez Arystotelesa powinno być ustalenie tego, co rzeczywiście się zdarzyło, nie zaś tego, co zdarzyć się tylko mogło 28 .

\section{WAŻNIEJSZA CYTOWANA LITERATURA}

J. Ad a mu s: Polska teoria rodowa, Łódź 1958

J. A d a mu s: Monarchizm i republikanizm w syntezie dziejów Polski, Łódź 1964

Arystoteles: Poetyka, w: Trzy poetyki klasyczne. Arystoteles, Horacy, Pseudo-Longinos, tłum. i oprac. T. S in ko, Wrocław 1951, s. 3-63

J. Bieniak: Średniowieczne polskie rody rycerskie. Stan badań, problemy sporne, możliwości badawcze, w: Genealogia - stan badań i perspektywy badań nad społeczeństwem Polski średniowiecznej na tle porównawczym, red. J. Pakulski, J. Wro nisze wski, Toruń 2003, s. $47-74$

M. C e tw iń s ki : Spór o istotę historii. Dyskusja wokół bitwy legnickiej w najnowszej historiografii, w: t e n ż e : Metamorfozy śląskie. Studia źródłoznawcze i historiograficzne, Częstochowa 2002 , s. 171-184

M. C e twińs si : Historia i polityka. Teoria i praktyka mediewistyki na przykładzie badań dziejów Śląska, Kraków 2008

J. Klapper: Die Tatarensage der Schlesier, „Mitteilungen der schlesischen Gesellschaft für Volkskunde", Bd 31/ 32: 1931, s. 160-196

S. Koś c i ł ko w s ki : Historyka. Wstęp do studio historycznych, Londyn 1954

S. Ku ra ś: Przywileje prawa niemieckiego miast i wsi małopolskich XIV-XV wieku, WrocławWarszawa-Kraków 1971

J. Matus zewski: Relacja o najeździe tatarskim w 1241 roku. Polskie zdania legnickie, Łódź 1980

J. Matus zew ski: Zaginiona kronika (RKD) Gerarda Labudy w oczach W. Sobocińskiego, w: te nż e: Pisma wybrane, t. IV, łódź 2001, s. 275-290

L. Schulte: Ist die Namensform Mieczko berechtigt? Eine quellenmäßige Untersuchung, "Zeitschridt des Vereins für Geschichte Schlesiens", t. 50: 1916, s. 68-129

${ }^{28}$ Arystoteles: Poetyka, w: Trzy poetyki klasyczne, tłum. i oprac. T. Sinko, Wrocław 1951, s. 19:

Między historykiem bowiem i poeta zachodzi różnica nie tylko w tym, że jeden posługuje się prozą, a drugi wierszem ( bo można by dzieło Herodota ułożyć w wiersze, a niemniej byłaby to jakaś historia, czy to wierszem, czy prozą), ale owa różnica polega raczej na tym, że jeden powiada o tym, co się rzeczywiście stało, a drugi, co się mogło było stać. 